介

殹動のルーッ送風機で行っている。乙の機関の排気管 の長させ $1 ， 3,5 \mathrm{~m}$ 亿変え，各回転数に対する排気

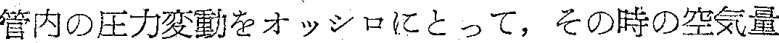

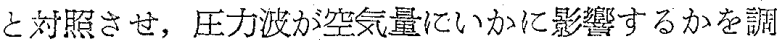

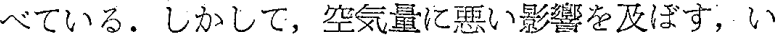
わゆる其振回転数が，訊算认よってあらかじめ求めう るととを示している。文た送風機を睓動するVベルト の張力によって，筀気量が影響されるてとにも言放し そのすべりと，ブースト圧，空気量などの夙係を実験 的に示しているのは特異である。【閣 敏郎】

\section{1. $43-242$}

[20]ピストンの設計 [AuŁo. Engr., 1953-6, Vol. 43, No. 567 , p. 223 234, 図 25] ピストン は最近で住専門製作所にまかせる事が多いが，機関設 訐者としても知って置くべきことについて述べてあ

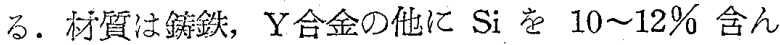
だ低浲膨脹 A1 合金が多く便われるが，その理由はダ イ銑物によく冷間のすきむを減らせる。代上はリング みぞが最も重要げが面はダイヤモンドテップの工具で 仕上げるのが良い。すを部には摩耗ばあまり起らな い. 重要なのは温度だがその検討には運転 50 時間後 切断し大きな球でブリネルかたさを測ってみると分 有肪わ汃る。過負荷で $375^{\circ} \mathrm{C}$ 定格で $350^{\circ} \mathrm{C}$ くらい までからる。リング带部で $212^{\circ} \mathrm{C}$ を越させてはなら ぬ. デタージェシトの入った滑油を使うと更に $25^{\circ}$ 上 げられる。冠部はむくになった縦りブですそ部を強め

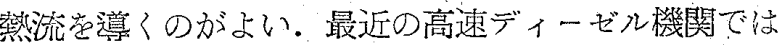
頂部で最大冷態すきまがシリンダ径の0.004 越すと とはない，冠部のリブはガジョンピン軸值角に置～

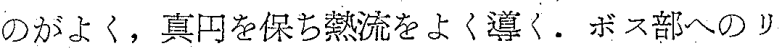
ブは長方形断面のむくのものが堌えた。リング部は諘

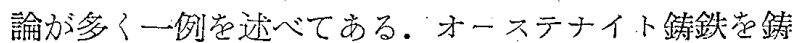
込んだみぞの摩耗を防ぐ方法は頂上リングみぞのみか

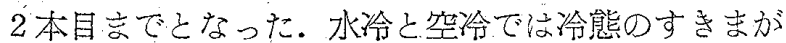
50\%異なる，最後にピストン製作所に発注する時の詿 要目学例示してある.

〔菓孝行〕

621. 436 I. $016.4-57$

[21]. ディーゼル秋関浪 $-54^{\circ} \mathrm{C}$ 宗で始動可能 [D. E. Kilty, N. K. Lammers ard K. J. Fleck, S.A.E., J., 1953-2,Vol. 61, No. 2, p. 36〜40, 困 4, 表 1] ディーゼル機関の寒地運転の問題は始動にあって，
一たん動き始めると問題はない，第1のす法は冬中回 して置くことだが，始動の時間を要せず熱源が内部に

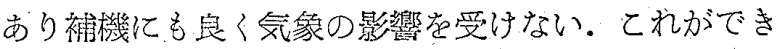
邓時仙他電気のでと等源を求め，機関停止と其に 点ずる。これらが共にできぬ時,特に軍用では $-18^{\circ} \mathrm{C}$

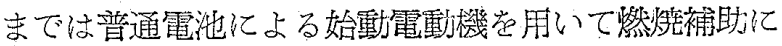
伖大管にエーテル炭入れるか子予熱グロープラグを使 う. $-32^{\circ} \mathrm{C}$ までは襍助ガソリン機閣により始彭し冷 却水，吸大空気学同時に予熱する。 - $45^{\circ} \mathrm{C}$ までは特 殊電池始衡の襍助ガソリン機関をエーテルを用いて始 動する。それ以下 $-54^{\circ} \mathrm{C}$ まではガソリントーヂを㳀 いて補期始動機関を温め, 特殊ガソリンで始動しディ 一ゼル機関にはエーテルを脚，吸大空気，冷媒，潤滑 油のみでなくクランキング系をすべて温める。てのガ ソリントーチはー $54^{\circ} \mathrm{C}$ まで点火可能で電湤も要らず, 保守も容易であり然料も特殊なもの要しないので便 利である。亲た気温とシリンダ容積当り $7 \cdot 5 \mathrm{cc}$ のカ プセル入エーテルを何個用いるべきかの図为市る。

[東 莩行]

\subsection{8}

〔22〕 [F. R. Bell, The Oil Engine and Gas Turbine, 1953-7, p. 114 116, 図 6] 座策用小形ガスタービンの出力, 構造, “運転 時間, タービン型式等につき論じ,小形タービンにふく 流型が用いられつつある今日むしろてれて批判的なの

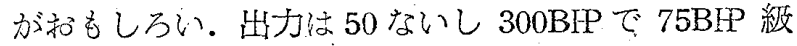
が最も态用のきくものとしている。タービン坃格は連 続所要出才の㭙間により大いに異なり，機関の贡称定 格は最大連続䄪 1 時間のポータブル消防ポンプか, 長 時間運転の発電機用かによりかなり異なる。構造的に は送風機，タービン等の組合せで 5 種類の基本型式を あげ解説している。一例として重量 $45 \mathrm{~kg}$ ，出才扰よ び Tife $50 \mathrm{P}$ で $5000 \mathrm{~h}, 75 \mathrm{P} 500 \mathrm{~h}, 100 \mathrm{P} 5 \mathrm{~h}$ ，一彯 式で送風機 $50000 \mathrm{rpm}$, 出打軸 $4000 \mathrm{rpm}$, 空気流䁷 $0^{\circ} 7 \mathrm{~kg} / \mathrm{s}$, 然比 $0^{\circ} 6 \mathrm{~kg} / \mathrm{BHPh}$ というすの字げている.

ふく流タービンについては，現在まだ結論にははど遠

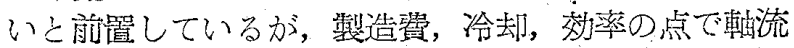
を支持し，ととに費用の点では，翼，雪板一体の才が ふく流型より鉔造し易々，鋳造でもふく流は50\%余訐 に材粼を食うから結局鞇流型の方力゙良いとしている。

〔関根 正信〕

\title{
9. 航空機抽よび航空發動機
}

\section{13.035}

[23]ロケット推僬の檴娥要素 [George P. Sutton, Rocket Propulsion Elements, 1949, John Wiley \& Sons, pp. 294, $140 \times 215 \mathrm{~cm}, 2000$ 四了。ロケット 推進の入門書であって，1. 分類と定議 2 . ロケット の歴更 3.ノズルと萪力学 4 . ロケット推薬の性能 訂算 5. 薬渡 6 . 口ケッ卜原動機 7 . 薬液供給装置

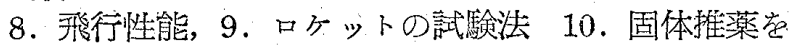
用いるロケット扣よび葉引胁ら成っていて各章に参考 文献方ついている。

ロクット工学を始める人には理論に片よらず実例に

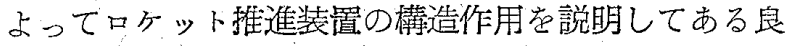
い入門書である。

\section{1. $431.75+621.45$}

[24] 世界の航空無動機 1953 年版 [Aircraft Engines of the World, Paul H. Wilkinson 著执よび 発行, pp. 320 , 写真多数, 表 8] 文ーボジェット と往復毁機関の 2 部に分けターボジェット 40 種, Afterburner 付 12 種，ターボプロップ 12 種を一覧 袁にし，別に 69 種のターボジェット执よび補助がス タービン 6 種について写真と共に詳し〈解説を附して いる. 更に往復埕機関 71 種について同様写真々解説 をのへている、その各部の初めに各国の生座会社と機 種についてのべている.

ジェット発勳機についていうとスラスト $10000 \mathrm{lb}$ (4.535 kg) 溹でなく生産に大っている. 12000 